\title{
Underutilized Fruits and Vegetables in Hot Arid Regions of India: Status and Prospects: A Review
}

\author{
P.R. Meghwal, Akath Singh, Dalpat Singh
}

10.18805/ag.R-2087

\begin{abstract}
The hot arid regions in India is spread in an area of $31.7 \mathrm{~m}$ ha, majority area being in Rajasthan (61\%). The great Indian Thar desert is also located in this region. This region receives vary low rain fall with erratic distribution. Presence of harsh climatic condition such as high evapotranspiration, low relative humidity, with high aridity index and high wind velocity are other disadvantages. The soils are also light textured, less fertile, and prone to wind erosion. About 90 per cent of the area is dependent on monsoon rain for growing of annual crops which often fails due to insufficient rain or improper distribution. Despite these limitations, the region has good floral and faunal diversity that supports high human and livestock population. Many drought hardy perennial fruits and vegetables are grown with annual crops to complement farm income. Certain fruit crops like pomegranate (Punica granatum), Indian jujube (Ziziphus mauritiana Lam.), aonla (Emblica officinalis), date palm (Phoenix dactylifera) and Citrus species are grown commercially in irrigated areas. Many underutilized fruit crops also grow naturally or are cultivated. These include kair (Capparis decidua), lasora (Cordia myxa) jhar ber (Ziziphus nummularia), bordi (Ziziphus rotundifolia) pilu (Salvadora oleoides), khejri (Prosopis cineraria), phalsa (Grewia subinaequalis), Bengal quince (Aegle marmelos), karonda (Carissa carandas), prickly pear (Opuntia ficus-indica), kachri (Cucumis melo var. callosus) and snap melon(Cucumis melo var. momordica) etc. Most of these species are drought hardy with less incidence of pests and diseases yet give good yield despite environmental constraints. They serve as a source of nutrition for rural people being rich in vitamins, minerals, dietary fibres and other bioactive compounds. Germplasm collection, evaluation, conservation, ethnomedicinal values, improvement, propagation, agrotechniques, post-harvest management, value addition and future prospects of some of these crops are discussed in the paper.
\end{abstract}

Key words: Agrotechniques, Hot arid region, Underutilized fruits drought.

Twelve per cent (39.54 $\mathrm{m}$ ha) of geographical area of India is occupied by hot and cold arid regions with majority area $(80 \%)$ in hot arid region. The hot arid regions are characterized by low rain fall $\left(100-400 \mathrm{~mm} \mathrm{y}^{-1}\right)$ with erratic distribution $(\mathrm{CV}>50)$, extremes of temperature $\left(0-50^{\circ} \mathrm{C}\right)$ in different seasons, high wind speed and high evapo transpiration $\left(1600-2000 \mathrm{~mm} \mathrm{y}^{-1}\right)$. The light sandy soil is poor in nutrients and low water retention ability, poor ground water resources and brackish water in most areas are other concerns. These regions are most fragile and have many productivity constraints besides biotic and abiotic stresses. However, the region is endowed with most adapted plant species, provide sustenance to the inhabitants. Certain climatic conditions help in the development of qualities in fruits and vegetables. Adverse climatic conditions and low humidity are also unconducive for the occurrence of diseases and pests. Intense solar radiation and high wind velocity are boon for generation of renewable energy. Most of the indigenous fruits and vegetables can be grown as rainfed or with harvested rain water.

Underutilized plant species can be defined as the one, which have received less attention of the researchers with respect to their improvement, agrotechniques, propagation, conservation utilization and trade. Agent (1994), considered underutilized fruit crops as the crops which have value but not widely grown, rarely found in the market and not
ICAR- Central Arid Zone Research Institute, Jodhpur-342 003, Rajasthan, India.

Corresponding Author: P.R. Meghwal, ICAR- Central Arid Zone Research Institute, Jodhpur-342 003, Rajasthan, India.

Email: prm20964@gmail.com

How to cite this article: Meghwal, P.R., Singh, A. and Singh, D. (2021). Underutilized Fruits and Vegetables in Hot Arid Regions of India: Status and Prospects: A Review. Agricultural Reviews. DOI: 10.18805/ag.R-2087.

Submitted: 22-08-2020 Accepted: 26-12-2020 Online: 11-02-2021

cultivated commercially. Several less-known fruit species which have the potential for commercial exploitation are yet to be utilized to their potential (Pareek and Sharma, 1993). Most of these species have wide adaptability as well as high degree of tolerance to stresses and can thrive even under most adverse situations (Mitra et al. 2010). There are approximately 600 species of tropical and subtropical region which are more known in their areas of diversity and have not yet been utilized to their full potential (Barua et al. 2019). These species serve as protective food for people living in unprivileged rural areas to meet their requirements of vitamins and minerals. Such fruits have been used in Indian system of medicine since ages due to their curative properties and being organic by default. Apart from their 
nutritive and medicinal values some of these have excellent flavor, attractive colour and high dry matter content are suitable for processing. Moreover, underutilized fruits of hot arid region often play important role of safety net in poor communities for complementing food security, nutrition health and income generation besides adding to environmental services. Despite these special quality attributes most of them have not been domesticated and hence their cultivation is very restricted and their use is mainly from naturally grown population. However, in past two decades, efforts have been made towards collection, evaluation, improvement, propagation and development of improved agrotechniques at least in some of these fruits and vegetables (Table 1)

\section{Lasora}

Lasora or gonda (Cordia myxa L.) belongs to family Boraginaceae is found grown in arid and semi-arid regions of north India. Its drupaceous fruits are edible with mucilaginous epicarp which constitute about $70 \%$ of fruit weight. The unripe fruits of lasora are used as vegetable, pickled with raw mango and can be dehydrated. The fruits and other plant parts have curative properties in skin diseases, dropsy, dysentery, dyspepsia, cholera and headache etc. Trees are mostly planted around farm as wind break and shelter belt however during past one decade, it is also planted as planned orchard. The species is deciduous medium sized tree having winter dormancy. Looking to their economic value and drought hardy nature, work on its survey, collection, evaluation and improvement were initiated during 2000-2001. The fruit pulp is rich in crude protein, fibre, carbohydrates and minerals. Eighteen germplasm accessions were collected and evaluated for higher fruit yield by selection. Four high yielding genotypes having bold fruit size (CZCM-2011, CZCM -2012, CZCM -2021, CZCM -2025 and CZCM -2062) were identified. Subsequently accession no. CZCM -2025 was released as Maru Samridhi (Meghwal and Singh, 2019a). Evaluation of different genotypes on three types of rootstocks revealed small fruited wild type as the best rootstock for commercial big fruited lasora irrespective of genotypes (Meghwal et al., 2014). Propagation through budding has been standardized with maximum bud take when it was done on $15^{\text {th }}$ August $(95 \%)$ on lasora seedling rootstock (Meghwal, 2007).

Agrotechniques have been developed to take early and uniform fruiting by defoliation and irrigation scheduling. Regular irrigation is given during establishment phase (3-4 years) after which no irrigation is required during monsoon and winter season (November-January) except occasional lifesaving irrigation (Meghwal et al. 2018a). Defoliation may be done with foliar spray of 1000 ppm of 2-chloroethyl phosphonic acid during first week of January. The irrigation is started from February onwards after manuring with the rise in temperature. The new growth and flowering start almost simultaneously. Regular irrigation is continued till end of April or when fruit harvest is completed. The fruits attain marketable maturity after 30-45 days of fruit setting. Mature green fruits are harvested before ripening. On ripening, the fruits turn yellowish brown, they are very sweet and edible but have little commercial value though, they can be used for extraction of seeds for raising nursery.

\section{Karonda}

Karonda (Carissa carandas L.) is a highly branched evergreen spiny shrub or a small tree. It belongs to family Apocyanaceae has multiple uses in home gardening and as protective live fence around commercial fruit orchards. It can grow up to $6 \mathrm{~m}$ if allowed to grow freely, however, its growth is regulated according to requirement and purpose. Besides its value in hedge and fruits, it also has ornamental value in its white fragrant flowers which looks very attractive during full moon light. The berry like fruits of karonda are quite attractive in appearance and rich in iron, calcium, magnesium, phosphorus and vitamin $\mathrm{C}$. It is native to India but also widely grown in South Africa and Malaysia. Karonda flowers in March-April and fruit mature from June to September in different varieties. In view of its wider adaptability in arid and semi-arid areas, the work on germplasm collection, evaluation and characterization was undertaken from 2000-2016.Seven germplasm accessions from different parts of India and one variety were evaluated. Good diversity in canopy volume, plant height, growth habit, precocity, morpho-physico-chemical characteristics of leaves, fruits and fruit yield were recorded (Meghwal et al. 2014). Based on the performance of the germplasm over a period of eight years for fruit yield and other desirable attributes, the accession Nos.CZCC-2011, CZCC-2022 and CZCC-2031 could be found suitable for hot arid zone due to their higher yield and bold fruit size. Subsequently one of the accessions (CZCC-2011) was released as Maru Gaurav an improved high yielding variety (Meghwal et.al., 2019b).

\section{Kair}

Kair or ker (Capparis decidua Forsk.) is a shrub or small tree belonging to family Capparaceae which comprises about 30 genera and 600 species. In India, about 26 species are reported (Heywood,1978) which are distributed in arid and semi-arid regions (Bhandari,1990). The species play ecological roles in providing vegetative cover, improve soil fertility, prevent soil erosion and promote biodiversity besides its economic significance (Shankarnarayan et al. 1987). It is found growing naturally along farm boundaries, orans, gochar and wasteland and widespread in different habitats. Kair is very important plant for forestry and horticulture. It is also an ideal plant for stabilizing sand dunes and controlling soil erosion, especially wind erosion since it grows naturally under rainfed situation. The fruits of kair have high economic value. The immature fruits are rich in carbohydrates, protein and mineral elements (Chouhan et al. 1986). The green immature fruits are highly valued for preparation of vegetables and pickles either alone or in combination with others. The fresh fruits are astringent due to presence of 
Table 1: Important underutilized fruits and vegetable in hot arid region of India-Improvement and agrotechniques.

\begin{tabular}{|c|c|c|c|c|}
\hline Crops & Improved varieties & Planting space $(\mathrm{m})$ & Propagation technique & Important agrotechniques \\
\hline $\begin{array}{l}\text { Lasora } \\
\text { (Cordia myxa) }\end{array}$ & $\begin{array}{l}\text { Maru Samridhi, } \\
\text { Karan Lasora, } \\
\text { Thar Bold }\end{array}$ & $6 \times 6$ & Budding & $\begin{array}{l}\text { Defoliation and irrigation scheduling, } \\
\text { crop regulation, processing } \\
\text { and value addition }\end{array}$ \\
\hline $\begin{array}{l}\text { Karonda } \\
\text { (Carissa carandas) }\end{array}$ & $\begin{array}{l}\text { Maru Gaurav, } \\
\text { Thar Kamal, } \\
\text { Pant Manohar, } \\
\text { Pant Suverna }\end{array}$ & $\begin{array}{l}2-5 \\
\text { depending } \\
\text { upon } \\
\text { purpose }\end{array}$ & $\begin{array}{l}\text { Seed, air } \\
\text { layering, } \\
\text { budding }\end{array}$ & $\begin{array}{l}\text { Crop regulation, irrigation } \\
\text { management, processing } \\
\text { and value addition }\end{array}$ \\
\hline $\begin{array}{l}\text { Kair } \\
\text { (Capparis decidua) }\end{array}$ & - & $5 \times 5$ & Seeds, cutting & $\begin{array}{l}\text { Harvesting, marketing } \\
\text { and value addition }\end{array}$ \\
\hline $\begin{array}{l}\text { Khejri } \\
\text { (Prosopis cineraria) }\end{array}$ & $\begin{array}{l}\text { Thar Shobha, } \\
\text { CAZRI Khejri-1, } \\
\text { CAZRI Khejri-2 }\end{array}$ & $6 \times 6$ & Budding & $\begin{array}{l}\text { Harvesting, marketing } \\
\text { and value addition }\end{array}$ \\
\hline $\begin{array}{l}\text { Bordi } \\
\text { (Ziziphus. Rotundifolia) }\end{array}$ & Tikadi, Vikas & $6 \times 6$ & Seeds, budding & $\begin{array}{l}\text { Seed extraction and nursery } \\
\text { techniques for raising of rootstocks }\end{array}$ \\
\hline $\begin{array}{l}\text { Jhar ber } \\
\text { (Zizizphus nummularia) }\end{array}$ & - & $3-5$ & $\begin{array}{l}\text { Seeds, root } \\
\text { suckers }\end{array}$ & Heading back at right time \\
\hline $\begin{array}{l}\text { Pilu } \\
\text { (Salvadora oleoides) }\end{array}$ & - & $7 \times 7$ & Seeds & $\begin{array}{l}\text { Harvesting, processing, } \\
\text { and value addition }\end{array}$ \\
\hline $\begin{array}{l}\text { Bael } \\
\text { (Aegle marmelos) }\end{array}$ & $\begin{array}{l}\text { NB-9, NB-5, } \\
\text { Goma Yashi, } \\
\text { Thar Divya, } \\
\text { Thar Neelkanth }\end{array}$ & $6 \times 6$ & Budding & $\begin{array}{l}\text { Irrigation management, processing } \\
\text { and value addition }\end{array}$ \\
\hline $\begin{array}{l}\text { Mulberry } \\
\text { (Morus spp) }\end{array}$ & $\begin{array}{l}\text { Thar Lohit, } \\
\text { Thar Harit }\end{array}$ & $6 \times 6$ & $\begin{array}{l}\text { Cutting, patch } \\
\text { budding }\end{array}$ & $\begin{array}{l}\text { Harvesting, handling, } \\
\text { processing and value addition }\end{array}$ \\
\hline $\begin{array}{l}\text { Drumstick } \\
\text { (Moringa oleifera) }\end{array}$ & $\begin{array}{l}\text { PKM-1, } \\
\text { Thar Harsha }\end{array}$ & $5 \times 2.5$ & Seeds, cutting & $\begin{array}{l}\text { Pruning,nutrient management, } \\
\text { harvesting at right stage }\end{array}$ \\
\hline $\begin{array}{l}\text { Khirni } \\
\text { (Manilkara hexandra) }\end{array}$ & $\begin{array}{l}\text { GK-1, GK-2, } \\
\text { Thar Rituraj }\end{array}$ & $8 \times 8$ & Soft wood grafting & Dehydration \\
\hline $\begin{array}{l}\text { Prickly pear } \\
\text { (Opuntia ficus-indica) }\end{array}$ & $\begin{array}{l}\text { RojaxRoja-4 } \\
\text {-Pianta-25, } \\
\text { Biananco } \\
\text { Macomer, }\end{array}$ & $\begin{array}{l}5-7 \mathrm{~m} \text { between } \\
\text { rows and } 1-2 \mathrm{~m} \\
\text { within rows } \\
\text { Clone No.1308, } \\
\text { Clone No.1270 }\end{array}$ & $\begin{array}{l}\text { Cladode segments } \\
\text { during February } \\
\text {-March }\end{array}$ & $\begin{array}{l}\text { Pruning management, handling, } \\
\text { processing and value addition }\end{array}$ \\
\hline $\begin{array}{l}\text { Phalsa } \\
\text { (Grewia subinaequalis), }\end{array}$ & $\begin{array}{l}\text { Thar Pragati, } \\
\text { Sharbati }\end{array}$ & $\begin{array}{l}\text { Paired row at } \\
3 \mathrm{~m} \text { and } 60 \mathrm{~cm} \\
\text { within rows }\end{array}$ & Hard wood cutting & $\begin{array}{l}\text { Pruning, harvesting, handling } \\
\text { and value addition }\end{array}$ \\
\hline $\begin{array}{l}\text { Tamarind } \\
\text { (Tamarindus indica) }\end{array}$ & $\begin{array}{l}\text { PKM-1, } \\
\text { Goma Prateek }\end{array}$ & $10 \times 10$ & $\begin{array}{l}\text { Seeds, soft } \\
\text { wood grafting, } \\
\text { patch,budding }\end{array}$ & $\begin{array}{l}\text { Harvesting at proper stage and } \\
\text { processing }\end{array}$ \\
\hline $\begin{array}{l}\text { Jamun } \\
\text { (Syzygium cumunii) }\end{array}$ & $\begin{array}{l}\text { Goma Priyanka, } \\
\text { Thar Kranti }\end{array}$ & $8 \times 8$ & $\begin{array}{l}\text { Patch budding, } \\
\text { soft wood grafting }\end{array}$ & $\begin{array}{l}\text { Harvesting, handling, processing } \\
\text { and value addition }\end{array}$ \\
\hline $\begin{array}{l}\text { Wood apple } \\
\text { (Feronia limonia) }\end{array}$ & - & $8 \times 8$ & Seeds, and budding & $\begin{array}{l}\text { Harvesting of fruits at appropriate } \\
\text { stagefor different processed } \\
\text { product preparation }\end{array}$ \\
\hline $\begin{array}{l}\text { Kachri } \\
\text { (Cucumis melo } \\
\text { var. callosus) }\end{array}$ & $\begin{array}{l}\text { AHK-119 and } \\
\text { AHK-200 }\end{array}$ & $0.6 \times 2.5 \mathrm{~m}$ & Seeds & Harvesting, handling, dehydration \\
\hline $\begin{array}{l}\text { Snap melon } \\
\text { (Cucumis melo } \\
\text { var. momordica) }\end{array}$ & AHS-10AHS-82 & $0.6 \times 2.5 \mathrm{~m}$ & Seeds & Harvesting, handling, dehydration \\
\hline
\end{tabular}


tannins and other phenolic compounds which can be removed by certain technique (Meghwal and Azam, 2007). Harvesting of fruits at right stage of maturity is very important or else they lose its quality. The fruits harvested after 7-10 days of fruit set with 5-8 mm diameter during March-April was found ideal (Meghwal,2002). Cured fruits can be prepared into vegetable curry, pickle or sun dried for storage and future uses. Properly sun-dried immature fruits of kair are sold in the urban retail market @ INR Rs.1000-1500/per $\mathrm{kg}$ depending upon the size. The smallest sized fruits fetch maximum price. The peak season of availability of kair fruits in India is during March-April.

\section{Khejri}

Prosopis cineraria (L.) Druce commonly known as khejri or Shami is a deep rooted leguminous multipurpose tree endemic to hot Indian desert but also found in dry regions of Arabia. It is the most important component of rainfed arid farming system which boosts the growth and productivity of companion crops besides supplying nutritious fodder, fuelwood, small timber, gums and tannins. Its foliage is much palatable to small ruminants and camels. Khejri is one of the few tree species which grows and flourish against all sorts of climatic constraints which is evidenced by the fact that it produces new foliage, flowers and fruits during the driest months (March-June) of the year. It is possible because of its inherent drought resistance mechanisms, deep root system, small leaves and other characters. Immature pods of khejri are used as quality vegetable both in fresh and dehydrated forms while ripe dried pods having $9-14 \%$ crude protein and $6-16 \%$ sugar can be powdered and used in the preparation of baked products. Different plant parts are used in India, Pakistan, Bangladesh, the United Arab Emirates, Saudi Arabia and Iran for treating various ailments such as leprosy, leucoderma, dysentery, asthma, bronchitis, piles, jaundice and muscular tremors. In recent years khejri is being domesticated as horticultural crop due to its value of pods in different ways. Because of the prevalence of seed propagation, immense viability in pods size and quality exists in natural population which can be employed for selection of desirable pod types for culinary purposes. The variety Thar Shobha has been developed by selection having long thin pods with good quality attributes (Samadia, 2015). The desirable types can be multiplied by budding to maintain its genetic purity with reduced gestation period. Six germplasm accessions and a variety Thar Shobha evaluated for pod yield and pod characteristics showed significant variation in yield and morphological characteristics (Meghwal, 2018). Khejri based crop production site management approach has also been developed (Samadia, 2016) in hot arid region for sustainable income under rainfed conditions.

\section{Bordi}

Bordi (Ziziphus rotundifolia Lam.) is drought and frost resistant small tree found grown naturally in hot arid region with slightly higher rainfall zone $(250-450 \mathrm{~mm})$ than jhar ber which is abundant in comparatively drier zone with low rain fall $(100-250 \mathrm{~mm})$. Fruits of $Z$. nummularia are small in diameter $(3.5-8 \mathrm{~mm})$ and mature in early November as compared to Z. rotundifolia having larger fruit diameter(8$20 \mathrm{~mm}$ ) with maturity in February-March. Z. rotundifolia trees are concentrated at places having abundant soil moisture, i.e. along the banks of rivers and around the water bodies. Good tree density (25-30/ha) of Z. rotundifolia were reported in younger alluvial plains of Western Rajasthan (Vashishtha, 1981). Z. rotundifolia has become an important rootstock for propagation of commercial varieties of Indian jujube (Z.mauritiana ). Bordi fruits have hard seed coat which has to be broken carefully to be used as rootstock. Each stone has two seeds called kernel. The seed kernel has high economic importance because it can be sold to commercial nursery at very high rate (About INR 3000/kg). Besides the value of fruits and leaves as fodder for livestock, bordi wood finds uses in house posts and agricultural implement handles being durable and strong.

\section{Jhar ber}

Jhar ber (Ziziphus nummularia Burm f.) is an important component of arid rainfed farming system as one of the perennial components of agri-horti and agri-pastoral system in arid and semi- arid regions of India. Since the economy of most of the farmers in hot arid regions is based on animal husbandry, jhar ber along with khejri provide sustenance to livestock as a source of fodder when ground cover is depleted in post monsoon season. It can grow in any kind of habitats but commonly found in crop lands and grazing lands (Kumar et al. 2005). It grows naturally on farm lands and spread through root suckers and also by seeds. Underground plant parts of jhar ber remain dormant during summer season and start resumption with the onset of monsoon and complete life cycle with flowering and fruiting by November-December before soil moisture depletion. The farmers head back the bushes from ground level at the end of kharif season for fodder purpose. The general practice is to collect the freshly cut thorny branches with leaves in small heaps and left for drying in the Sun. After Sun exposure for 6-7 days, the leaves fall off naturally with little shaking. The dried leaves called pala locally are separated from thorny bushes for feeding to livestock while the thorny materials are useful for fencing purpose. The fruits are mostly round berries having green colour when immature which turn yellow or red at maturity and dark brown after drying. The fruits ripen during late November and December and eaten fresh as well as after drying. It contains considerable amount of soluble carbohydrates. The dried fruits are grounded with the stone and sieved. The sieved powder is consumed after meal as mouth freshner is very rich in sugar, ascorbic acid and protein. Leaves locally called pala are rich in protein $(12.9-16.9 \%)$ and crude fibre) and very palatable to small ruminants and camels.

\section{Peelu}

Peelu (Salvadora oleoides Decne) is drought hardy species 
native to hot arid regions of India and found grown naturally mainly in Rajasthan and Gujarat. Another closely related species is $S$. persica which is also equally important and found in the same agroclimatic region. The species is also reported to occur in tropical Africa and Asia extending to Egypt, Mascarene Island and China (Anon.1972). It is native of Sub-tropical to Tropical Africa and also grows widely in Egypt, Tanzania, Middle East, India, China, Persia and Malaysia. In India, its natural occurrence is confined to Rajasthan, Gujarat, Haryana, and Punjab and to some extent in Andhra Pradesh, Karnataka and Tamil Nadu. Peelu has great tolerance against abiotic stresses such as moisture, temperature and salinity. The tree is small to medium in size with dense foliage. Apart from edible fruits, other plant parts are important economically. Leaves are very good feed for animals especially goats and camels which browse on this species along with other species while the twigs are used for cleaning the teeth. The root bark and leaves etc. have value in folk medicine. The species flower during March-April and fruit ripe during May-June under high temperature and moisture stress situation taking the water from deep strata of the soil. The immature fruits are acrid but fully ripened fruits are quite sweet with TSS of 18-22 ${ }^{0}$ Brix (Khan et al. 2005). Great deal of variability in fruit shape, size and colour are found due to seed propagation. The fresh fruits contain about $70 \%$ juice which is suitable for processing. Khan et al. (2005) standardized the technique of juice extraction and preparation of products like squash, jam, nectar and fruit dehydration techniques. The seeds are rich in non-edible fat (40-50\%) might have industrial value for preparation of soaps and candles. After extraction of oil the cake is also useful as manure.

\section{Bael}

Bael (Aegle marmelos) is an important member of citrus family Rutaceae. It is native of India and grows wild in submountainous regions of south east Asia including India, Pakistan, Sri Lanka, Bangladesh and Thailand. In India, bael is grown in tropical to subtropical regions including hot arid regions. This plant is store house of nutraceuticals as almost each plant part and fruits are useful. The fruit is very rich in sugar, riboflavin and minerals is a tonic, restorative, laxative and good for heart and brain. The mature fruit is astringent, digestive and stomachic and is usually prescribed for diarrhea and dysentery. A variety of processed product like squash, ready to serve drinks, preserve, candy etc. can be prepared out of bael fruit pulp. The naturally occurring population of bael tree is of seedling origin and has tremendous diversity in vegetative and fruit characteristics. Utilizing the rich diversity of native germplasm, a number of improved varieties have been developed by different research institution mainly through selection and maintained subsequently by vegetative propagation method. These include NB-5, NB-7, NB-9, NB-16, NB-17, Pant Aparna, Pant Sujata, Pant Shivani, Pant Urvashi, CISH B-1 and CISH B2(Singh et al. 2017; Mishra, 2007; Pathak et al. 2003; Singh et al., 2013; Shukla and Sanjeev Kumar, 2009), Goma Yashi (Singh et al. 2012), Thar Divya (Singh, et al., 2015) and Thar Neelkanth (Singh, et al., 2016).

\section{Mulberry}

Mulberry (Morus spp.) is a multipurpose plant grown around the world for sericulture, forage and fruits. In some Asian countries, mulberry leaves have been traditionally fed to farm animals. The higher biomass yield, the palatability and the exceptionally high nutritive value of the leaves has generated enormous interest in mulberry for animal feeding in recent years. For the purpose of fruits, white mulberry (Morus alba), black mulberry $(M$. nigra), Indian mulberry $(M$. indica) and the red mulberry ( $M$. rubra), Korean mulberry (Morus australis), Himalayan mulberry (M. laevigata) and many hybrid forms also exist between Morus alba and M. rubra and others. Though, mulberry is an industrial crop for sericulture industry, but immense potential also exists for commercial fruit production looking to its ability to grow in different types of soils and climatic conditions and diversity in fruit colour. The ripened fruits have rich aroma and sweet taste can be used as dessert as well as for processing. Mulberry cultivation for fruits can be taken up in wide ranging climatic conditions ranging from temperate to tropical and subtropical conditions. The hot arid regions having subtropical climate can be exploited for excellent quality fruit production of mulberry. High temperature tolerant varieties like Thar Lohit and Thar Harit have been developed for hot arid regions (Singh et al. 2018).

\section{Drumstick}

Drumstick (Moringa oleifera) is one of the world's most useful plants. This fast-growing tree is grown for human food, livestock forage, medicine, dye, composting, and water purification. The leaves of Moringa are highly nutritious being rich in beta-carotene, protein, vitamin $\mathrm{C}$, calcium, potassium and iron. The fruits or seed pods, known as drumsticks, is a culinary vegetable used in soups and curries. The leaves and flowers also have many culinary uses. The long drumsticks are often cut into shorter lengths and stewed in curries and soups. In developing countries, moringa has the potential to improve nutrition, boost food security, foster rural development, and support sustainable land management. It may be used as forage for livestock, a micronutrient liquid, a natural anthelmintic, and possible adjuvant. Large number of varieties have been developed for tropical conditions such as PKM-1, PKM-2 etc. and recently, a new variety Thar Harsha has specifically been developed for subtropical regions which withstands high temperature and drought (Raja et al. 2018).

\section{Khirni}

Khirni or Rayan (Manilkara hexandra Roxb. Dubard) is a minor underutilized fruit tree belonging to family Sapotaceae. It is an evergreen tree, native to Central and Deccan peninsular India. The tree is generally grown for its ornamental value and sweet edible fruits. The species is 
also important from economical and ethnomedicinal point of view and livelihood security of the tribal population. The fruits are rich in carbohydrates, minerals, protein and vitamin A. Trunk bark and fruits are used for treatment of several human diseases like ulcers, dyspepsia, bronchitis and leprosy etc. (Anon. 1962). Improved varieties like CISH K10 and Thar Rituraj have been developed in India which has mean fruit weight of $5.2 \mathrm{~g}, 87.49 \%$ pulp, $24.73^{\circ}$ Brix TSS, $0.32 \%$ titratable acidity, $17.8 \%$ total sugar, $9.23 \%$ reducing sugar and $28.33 \mathrm{mg} 100 \mathrm{~g}^{-1}$ of vitamin C contents (Singh et al. 2015).

\section{Cactus pear}

Cactus pear (Opuntia ficus-indica L.) has proved its usefulness as a crop of multiple importance, the world over. In India, many species of cacti are found growing naturally in arid and semi-arid regions or grown as ornamental plants in urban homes and gardens. Generally, these species are used as live fence to protect agricultural field from human and animal encroachments. Looking to specific phenological, physiological and structural adaptation of cacti, it can be considered to cope with the climate change in hot arid region. Opuntias have been exploited worldwide as fruit, vegetable, fodder and cochineal dye in variety of fresh and processed products. Effort to introduce the commercial varieties in India from commercial cactus growing countries were made as early as 1970 to study its adaptability, biomass production and fruits and fodder yield potential. In a renewed effort recently, its introduction and adaptability trials were initiated during 2010 with introduction of 43 cultivars from Italy through ICARDA (Roy et al. 2015). However, field performance of exotic cultivars at Jodhpur $\left(26^{\circ} 18^{\prime} \mathrm{N}: 73^{\circ} 04^{\prime} \mathrm{E}\right.$, $216 \mathrm{~m} \mathrm{MSL}$ ), India was very dismal due to bacterial rot at the base after field transplanting and restricted growth due to high temperature and less relative humidity during growing season while comparatively better performance was recorded at Kutch-Bhuj $\left(23^{\circ} 21^{\prime} \mathrm{N}\right.$ : $\left.69^{\circ} 77^{\prime} \mathrm{E}, 15 \mathrm{~m} \mathrm{MSL}\right)$ region of Gujarat being a coastal belt (Meghwal et al. 2018b).

\section{Phalsa}

Phalsa (Grewia subinaequalis L.) has originated from India is a short duration fruit crop of immense potential but it remained underutilized due to small sized perishable fruits which is difficult to transport to distant market. Asynchronous fruit maturity, lack of improved varieties and labour intensive harvesting are other factors responsible for its underutilization. Best quality in fruits is developed in dry and hot arid regions. It is propagated by hard wood cutting during rainy season. Treating the cutting with IBA@100 ppm for few second helps to enhance rooting in cutting. The fruits are borne in clusters in the axil of leaves on current year's growth and hence pruning is an essential operation. Under north Indian condition, pruning is done during middle of winter (Singh, 1979). In hot arid region of Rajasthan, pruning done in last week of December at $120 \mathrm{~cm}$ from ground level produced maximum fruit yield (Meghwal, 2006).

\section{Tamarind}

Tamarind (Tamarindus indica) is native to Tropical Africa and belongs to the family Fabaceae. The trees are evergreen, tall large sized with a spreading dense crown. The species is an excellent tree for social forestry and agro-forestry. It can withstand harsh climatic condition and suitable even in wastelands in hot arid region. Almost every plant part is useful apart from the sweet acidic fruits. The pulp has low water content and high levels of proteins, carbohydrates and minerals. The pulp is used as souring agent for squashes, chutney, beverages, etc. The fruit is used in the Indian medicine as a refrigerant, carminative, antiscorbutic and laxative and is also prescribed for bilious disorders. The active constituents present are furunone, phenyl acetaldehyde and tartaric acid. The products of the seeds are used mostly for manufacture of sizing powders. Tamarind kernel powder is extensively used for starching of cotton yarns, jute fabrics and woolen materials. The leaf sap possesses diuretic, antibacterial properties and nematode toxicity.

\section{Jamun}

Jamun (Syzygium cuminii Skeel) is an important underutilized fruit of Indian origin. It is also found in Thailand, West Indies, Philippines and other tropical and subtropical countries. The tree is ideally suited for windbreak and roadside plantations. Fruits contains carbohydrate, protein, iron, calcium, phosphorus, fat and fibre. The fruit is of much therapeutic and nutritive value which has been used in Indian and Ayurveda system of medicine since ages. The fruit is useful as dessert as well as after processing. It is useful for blood purification, diabetes, diarrhea, eczema and as an antidote for strychnine poisoning. It is also considered stomachic, carminative and diuretic and lowers the blood pressure. The jamun seed powder reduces the sugar content in urine. The fruit color is due to anthocyanin pigment. The fresh fruits are perishable but they are potential for processing (Roy et al.,1999). A variety of processed products such as Juice, squash, jam jelly, wine and vinegar can be prepared. A method of extraction of jamun juice and its processing to prepare juice and ready to serve nectar were standardized by Roy et al. (1999).

\section{Wood apple}

Wood apple (Feronia limonia) is drought hardy fruit native from India. It belongs to citrus family Rutaceae. The tree is semi spreading to erect in growth habit and produces nutritive acidic fruit with very high yield potential. The fruit pulp is creamy white when unripe but becomes brownish with pleasant aroma upon ripening. The fruit pulp can be eaten raw with some sugar. The pulp contains $18.1 \%$ carbohydrate, $7.1 \%$ protein, $3.7 \%$ fat, $5.0 \%$ fibre and $1.9 \%$ mineral matter. The pulp is a rich source of calcium, phosphorus, iron and vitamins like carotene, riboflavin, niacin, thiamine and vitamin $\mathrm{C}$. The fruit pulp can be used for making chutneys, pickle, jam, jelly and squash. The fruit 
is also used as a liver and cardiac tonic, and when unripe, for easing diarrhea and dysentery

\section{Kachri}

Kachri (Cucumis melo var. callosus) is a monoecious cucurbitaceous vegetable grown for its sweet acidic fruits during kharif and spring summer season in hot arid parts of India. Enormous variability in fruit size and color occurs as most farmers use their own seeds. However, some improved varieties like AHK-119 and AHK-200 have been developed recently which are much in demand and scientific production techniques have been standardized (Samadia et al. 2018). The entire fruit along with seeds are consumed after peeling. Mostly the fruits are used in combination with other vegetables such as cluster bean pods, radish leaves and Acacia senegal seeds where the role of kachri fruits is to impart better taste with sourness. Highly delicious preparation is made with green Acacia senegal seeds which are also available at the end of rainy season. The fruits also have very good shelf life (20-30 days) under ambient condition if harvested at mature un ripened stage. Locally the fruits are peeled, cut into transverse section and sun dried for storage up to one year under ambient condition and for use during off season. Better quality dehydrated product of kachri could be prepared by pretreatment of cut pieces with Sulphur dioxide fumes for three hours before dehydration in an electric drier (Meghwal, 2008). The dried fruits are grounded into powder to be used in preparation of breads and biscuits.

\section{Snap melon}

Snap melon (Cucumis melo var. momordica) Duthie \& Fuller commonly known as Phoot kakri is one of the most popular rainfed cucurbitaceous crops in hot arid region of India. It is a short duration drought hardy crop with deep tap root system often grown as mixed crop along with pearl millet, cluster bean, moth bean etc. in kharif season. Great deal of variability in fruit shape size, and colour has been reported (Samadia, 2007). Generally, the farmers use their own seeds for cultivation which results in inferior fruit quality but some improved varieties like AHS-10 and AHS-82 have been developed recently which have uniform fruit size and better quality (Samadia, 2007). Mostly the fruits are used as dessert after ripening. The fruits are good source of vitamin $C$, sugars, minerals and dietary fibre at a very cheap price. The fruits are also sun dried for future uses after removing the peel and cutting into longitudinal flakes. Seed kernels are extensively used in sweet, bakery products and traditional drink. The mature fruits give cooling effect, improve appetite and relieve constipation.

\section{CONCLUSION}

Despite the environmental constraints and low rain fall, the hot arid regions especially western Rajasthan are quite rich in numerous plant species. Many of the species, are rich in vitamins, minerals and possesses several nutraceutical properties and local inhabitants use them for centuries, but still scientific cultivation of these species is lacking. The factors responsible for their underutilization are lack of improved genotypes/varieties, improved agrotechniques, post-harvest technologies and marketing. Although some work on improvement and development of agro-techniques have been done or are being done in some of the crops, however, all the crops need to be explored. The variability present in natural population offers scope for improvement and selection of desirable types can be a very simple technique. The next step could be large scale multiplication of desirable genotypes and supplying the same to growers for commercialization.

\section{REFERENCES}

Agent (1994). A survey of the market for fruits and vegetables in the hotel and restaurant industry, Agent's business production, processing and marketing information centre, Issue No 19, Colombo, 2.

Anonymous (1962). The wealth of India: Raw materials, vol 6 . Publications and Information Directorate, CSIR, New Delhi, pp. 298-300.

Anonymous (1972). The wealth of India, Raw materials 9, 193, CSIR, New Delhi.

Bhandari, M.M. (1990). Flora of Indian Desert. MPS Repros, 39, BGKT Extension, Jodhpur (Rajasthan).

Barua, U., Das, R.P., Gogoi, B. and Baruah, S.R. (2019). Underutilized fruits of Assam for livelihood and nutritional security. Ag. Reviews. 40(3): 175-184.

Chouhan, B.M., Duhan, A. and Bhatt, C.M. (1986). Nutritional value of Ker (Capparis decidua) fruit. J. Food Sci. Tech. 23(2): 106-108.

Heywood, V.H. (1978). Flowering Plants of the World. Oxford University Press, London, $335 \mathrm{p}$.

Khan, H.A., Meghwal, P.R. and Harsh, L.N. (2005). Salvadora oleoides Decne: An underutilized economic plant of the desert. Science Tech. entrepreneur. 12(12): 61-64.

Kumar Suresh, Farzana Parveen and Pratap Narain (2005). Medicinal plants in the Indian Arid Zone. Technical bulletin CAZRI Jodhpur, pp.64.

Meghwal, P.R. (2002). Judging culinary maturity of Kair fruits (Capparis decidua). Curr. Agric. 26(1-2): 75-76.

Meghwal, P.R. (2006). Effect of time and intensity of pruning on vegetative growth, fruit yield and quality of phalsa. Annals of Arid Zone. 45(1): 59-62.

Meghwal, P.R. (2007). Propagation studies in lehsua (Cordia myxa). Indian J. Agri Sci. 77(11): 765-767.

Meghwal, P.R. and Azam, M.M. (2007). Prospects of horticultural crops of arid zone for processing industries. International Exhibition and conference on processed food. Aug. 29Sept., 2, 2007, Jaipur (Rajasthan).

Meghwal, P.R. (2008). Dehydration of fruits and vegetable from traditional farming systems of arid Zone. In: Diversification of Arid Farming System (Eds. Pratap Narain, M.P. Singh, Amal Kar, S. Kathju and Praveen Kumar). Arid Zone Research Association of India and Scientific Publishers (India), Jodhpur, pp. 405-407. 
Meghwal, P.R., Singh, S.K., Singh, A. and Pathak, R. (2014). Characterization of karonda accession under arid regions. J. App. Hort. 16(2): 157-160.

Meghwal, P.R. Singh, A. and Pradeep-Kumar (2014). Evaluation of selected gonda genotypes (Cordia myxa L.) on different rootstocks. Indian J. Hort. 71(3): 415-418.

Meghwal, P.R. (2018). Collection, evaluation and improvement of some underutilized fruits in hot Indian desert. Indian $\mathrm{J}$. Arid Hort. 13(1 and 2): 59-64.

Meghwal, P.R., Singh, A. and Singh, D. (2018a). Enhancing the Productivity of Lasora (Cordia myxa L.) through Genetic Improvement and Production Management. Paper presented in national conference on Arid Horticulture for Enhancing productivity and economic empowerment. 27-29 October, organized by Indian Society of Arid Horticulture and ICARCentral Institute for Arid Horticulture, Bikaner, Rajasthan, India.

Meghwal, P.R. Kumar, A. and Kumar, S. (2018b). Performance of Cactus pear at two geographical locations in Indian Arid Zone. Indian J. Hort. 75(1): 157-160.

Meghwal, P.R. and Akath, S. (2019a). Maru Samridhi: new lasora variety Indian Horticulture. 64(2): 32-33.

Meghwal, P.R. and Singh Akath and Singh, S.K. (2019b). Maru Gaurav: new karonda variety. Indian Hort. 64(2): 30-31.

Mishra, K.K. (2007). Cultivating promising bael selections. Indian Hort. 52(3): 13-15.

Mitra, S.K. Pathak, P.K. and Chakraborty, I. (2010). Potential of underutilized tropical fruits of India. Acta Hort. 864: 61-68.

Pareek, O.P. and Sharma, S. (1993). Underutilized fruits. Indian Hort. 38: 47-58.

Pathak, R.K., Pandey, D. and Pramamick, P.K. (2003). CISH B-1 and CISH B-2 -Two Promising selections in Bael. ICAR News 9(1): 16.

Raja, S., Apparao, V.V., Yadav, L.P., Singh, S. and Sharma, B.D. (2018). Thar Harsha: A new drought tolerant drumstick. Indian Hort. 63(3): 19-22.

Roy, S.K., Pal, R.K., and Ramanjaneya, R.H. (1999). Jamun: a potential fruit for processing. Indian. Hort. 44(2): 9-12.

Roy, M.M., Kumar, S., Meghwal, P.R. and Kumar, A. (2015). Prospects of Cactus Introduction for Improving Livelihood in Low Rainfall Regions of India. Acta Hort. 1067: 239-246.
Samadia, D.K. (2007). Underutilized arid vegetables. In: Underutilized and Underexploited horticultural crops, [Peter, K.V. (ed.)] New India Publishing Agency, New Delhi (India), Vol.2, pp.153-174.

Samadia, D.K. (2015). Khejri - Thar Shobha: Grow for horticultural exploitation. Technical Folder, ICAR-Central Institute for Arid Horticulture, Bikaner (Rajasthan), 6p.

Samadia, D.K. (2016). Khejri-Thar Shobha - Grow for Horticultural exploitation. Technical Folder, ICAR-CIAH, Bikaner, Rajasthan (India).

Samadia, D.K., Haldhar, S.M. and Verma, A.K. (2018). Underutilized Arid vegetables for income. Indian Hort. 63(5):47-52.

Shankarnarayan, K.A., Harsh, L.N. and Kathzu, S. (1987). Agroforestry in arid zones of India. Agroforestry Syst. 5: 69-88.

Shukla, S.K. and Kumar, S. (2009). Underutilized Subtropical Fruits, 184p. International Book Distributing Co., Lucknow, India.

Singh, R. (1979). Fruits. National Book Trust, New Delhi.

Singh, A.K., Singh, S., Joshi, H.K. and Singh, R.S. (2012). Goma Yashi to enrich fruit basket. Indian Hort. 57(5): 6-8.

Singh, A.K. Singh, S. and Joshi, H.K. (2013). Improving socioeconomics through rainfed bael. Indian Hort. 58(4): 14-17.

Singh, A.K., Singh, S., Singh, R.S. and Sharma, S.K. (2015). Thar Divya: an early maturing variety of bael for drylands. Indian Hort. 60(6): 11-13.

Singh, S., Singh, A.K., Apparao, V.V. and Bhargwa, R. (2015). Thar Rituraj: a new khirni variety. Indian Hort. 60(6): 14-15.

Singh, A.K., Singh, S., Singh, R.S. and Sharma, B.D. (2016). Thar Neelkanth: a new bael variety. Indian Hort. 61(5): 8-10.

Singh, A.K., Singh, S. and Saroj, P.L. (2017). Cultivating climate resilient bael for future. Indian Hort. 62(4): 43-45.

Singh, D. Singh, S. and Saroj, P.L. (2018). Improvement of fruit crops for Arid and semi-arid regions. In: Saroj, P.L., Bhargawa, R., Sharma, B.D., Singh, D. and Singh, S., Souvenir of National Conference on Arid Horticulture for Enhancing Productivity and Economic Empowerment at ICAR-CIAH , Bikaner. 27-29 October, pp. 46-50.

Vashishtha, B.B. (1981). Horticultural qualities of bordi (Ziziphus nummularia). In: Mann H S and Saxena S K (Eds). Bordi. (Ziziphus nummularia): A shrub of the Indian Arid zoneIts role in silvipasture. CAZRI Monogram No.13, ICARCAZRI, Jodhpur pp 31-33. 